\title{
The thermochemistry of alkanethiols and thioethers. Estimation of the enthalpies of formation of 1,3-dithiapropane and 1,3,5-trithiapentane
}

\author{
Rafael Notario* and María Victoria Roux \\ Instituto de Química Física “Rocasolano”, C.S.I.C., Serrano 119, 28006 Madrid, Spain \\ E-mail: rnotario@iafr.csic.es
}

Dedicated to Professor Eusebio Juaristi on his $55^{\text {th }}$ birthday

(received 30 May 05; accepted 11 Aug 05; published on the web 18 Aug 05)

\begin{abstract}
We have carried out a study on the thermochemistry of alkanethiols and thioethers. Relationships between the enthalpies of formation of alkanes, alkanethiols, and thioethers are discussed with the purpose of deriving different group interconversion contributions that permit the estimation of unknown $\Delta_{\mathrm{f}} H_{\mathrm{m}}^{0}(\mathrm{~g})$ values for alkanethiols and thioethers from known values of alkanes. We have also carried out a theoretical study at the G2(MP2), G2, and G3 levels, calculating the enthalpies of formation of two compounds, 1,3-dithiapropane and 1,3,5-trithiapentane, and comparing them with the values previously estimated.
\end{abstract}

Keywords: Alkanethiols, thioethers, 1,3-dithiapropane, 1,3,5-trithiapentane, enthalpies of formation, Gaussian-n calculations

\section{Introduction}

The structure and energetics of molecules are fundamental concepts in Chemistry, the energy associated with a particular structure being related to the constituent atoms, and the corresponding bonds and angles that form the molecular framework. ${ }^{1}$ Thermodynamic data such as the enthalpies of formation are often helpful in the understanding of the conformational and reactivity trends exhibited by the molecules. One of the purposes of thermochemistry is to derive the enthalpies of formation of compounds from their elements, and to relate them to structure and chemical binding. ${ }^{1-3}$

Several empirical methods have been applied to the calculation of enthalpies of formation of hydrocarbons and alkane derivatives. The simplest procedures for calculating values for standard enthalpies of formation assume that enthalpies of atomization of compounds may be represented by a sum of contributions from the constituent bonds. Sophisticated procedures 
require a large number of parameters and so less elaborate, more generally applicable, procedures are required. The three most commonly used are those due to Laidler, ${ }^{4}$ Allen ${ }^{5,6}$ and Benson. ${ }^{7,8}$ In the Laidler bond additivity approach, ${ }^{4}$ values for some bond energies are allowed to depend on the environments of the bonds. The Allen group increment method ${ }^{5,6}$ assumes constant values for bond energies, but also includes contributions from molecular fragments. The Benson group additivity scheme ${ }^{7,8}$ does not use bond energies and instead assumes that enthalpies of formation or atomization can be represented by contributions from different types of molecular fragments. The unified scheme of Cox and Pilcher, ${ }^{2}$ which consolidates the Allen, Benson and Laidler methods, is more sophisticated and has been applied almost exclusively to simple hydrocarbons.

More recently, the Pedley method ${ }^{9}$ that allows bond-energy terms to vary among a number of specific environments, and the additive bond-energy scheme of Smith ${ }^{10,11}$ that includes geminal $\mathrm{H}-\mathrm{H}$ terms have been developed.

In this work we have carried out a study on the thermochemistry of alkanethiols and thioethers. Relationships between the enthalpies of formation of alkanes, alkanethiols, and thioethers are discussed with the purpose of deriving different group interconversion contributions that permit the estimation of unknown $\Delta_{\mathrm{f}} H_{\mathrm{m}}^{0}(\mathrm{~g})$ values for alkanethiols and thioethers from known values of alkanes. We have also carried out a theoretical study at the G2(MP2), G2, and G3 levels, calculating the enthalpies of formation of two compounds, 1,3dithiapropane and 1,3,5-trithiapentane, and comparing them with the values previously estimated.

\section{Results and Discussion}

The known enthalpies of formation ${ }^{9}$ in the gas phase, $\Delta_{\mathrm{f}} H_{\mathrm{m}}^{0}(\mathrm{~g})$, of alkanes, alkanethiols and thioethers, have been collected in Table 1. As it is well known, ${ }^{2,12-17}$ the values of the thermodynamic properties of a homologous series, $\mathrm{Y}-\left(\mathrm{CH}_{2}\right)_{\mathrm{m}}-\mathrm{H}$, show a monotonic, often linear, dependence on $\mathrm{m}$. Prosen, Johnson and Rossini, ${ }^{13}$ proposed the general relation:

$\Delta_{\mathrm{f}} H_{\mathrm{m}}^{0}\left[\mathrm{Y}-\left(\mathrm{CH}_{2}\right)_{\mathrm{m}}-\mathrm{H},(\mathrm{g})\right] / \mathrm{kJ} \mathrm{mol}^{-1}=\mathrm{A}+\mathrm{Bm}+\delta$

where $\mathrm{A}$ is a constant peculiar to the end group $\mathrm{Y}$; $\mathrm{B}$ is a constant for all normal alkyl series, independent of $\mathrm{Y}$; and $\delta$ is a term which has a small finite value for lower members, being largest for $\mathrm{m}=0$, and becomes zero for higher members, beginning near $\mathrm{m}=4$. B values of $-20.71,-20.62$ and $-20.53 \mathrm{~kJ} \mathrm{~mol}^{-1}$ have been obtained by us for n-alkanes, 1-alkenes and 1alkynes, respectively, using the experimental data available in the literature. ${ }^{9}$ However, for 1alkanols, $\mathrm{B}$ has a value of $-20.13 \mathrm{~kJ} \mathrm{~mol}^{-1}$. The reason for the different methylene increment in 1 -alkanols is not well understood. ${ }^{11}$ In 1 -alkanethiols a $\mathrm{B}$ value of $-(20.80 \pm 0.18) \mathrm{kJ} \mathrm{mol}^{-1}$ is obtained, indicating that their behavior is similar to that generally observed, but different to that 
of 1-alkanols. A value of $-4.95 \mathrm{kcal} \mathrm{mol}^{-1}\left(-20.71 \mathrm{~kJ} \mathrm{~mol}^{-1}\right)$ was obtained by Good and DePrater ${ }^{18}$ using the data between 1-butanethiol and 1-decanethiol.

An interesting way in which data may be examined is via calculations of energies for converting one group, such as methyl or methylene, to another. Group interconversion is more satisfactory that replacement of a hydrogen by a functional group since nonbonded interactions will cancel to some extent in the former case but not in the latter. ${ }^{16}$

Following the ideas of Stull et al., ${ }^{19}$ Wiberg et al., ${ }^{15}$ and Slayden and Liebman, ${ }^{12}$ we can describe the energetics of alkanethiols and thioethers defining the quantities:

$\Delta \Delta_{\mathrm{f}} H_{\mathrm{m}}^{\mathrm{o}}\left[\mathrm{CH}_{3} \rightarrow \mathrm{SH},(\mathrm{g})\right]=\Delta_{\mathrm{f}} H_{\mathrm{m}}^{\mathrm{o}}[\mathrm{R}-\mathrm{SH},(\mathrm{g})]-\Delta_{\mathrm{f}} H_{\mathrm{m}}^{\mathrm{o}}\left[\mathrm{R}-\mathrm{CH}_{3},(\mathrm{~g})\right]$

$\Delta \Delta_{\mathrm{f}} H^{\mathrm{o}}{ }_{\mathrm{m}}\left[\mathrm{CH}_{2} \rightarrow \mathrm{S},(\mathrm{g})\right]=\Delta_{\mathrm{f}} H_{\mathrm{m}}^{\mathrm{o}}\left[\mathrm{R}-\mathrm{S}-\mathrm{R}^{\prime},(\mathrm{g})\right]-\Delta_{\mathrm{f}} H_{\mathrm{m}}^{\mathrm{o}}\left[\mathrm{R}-\mathrm{CH}_{2}-\mathrm{R}^{\prime},(\mathrm{g})\right]$

The variation of the $\Delta \Delta_{\mathrm{f}} H_{\mathrm{m}}^{\mathrm{o}}$ values for alkanethiols is small. Not taking into account the conversion from ethane to methanethiol, where a $\mathrm{CH}_{3}$ group attached to another $\mathrm{CH}_{3}$ group is converted to $\mathrm{SH}$, we obtain a mean value of $57.8 \pm 1.1 \mathrm{~kJ} \mathrm{~mol}^{-1}$, using 18 data points. In the case of thioethers, the $\Delta \Delta_{\mathrm{f}} H_{\mathrm{m}}^{\mathrm{m}}$ values present a wider range of values and the four compounds with higher deviations have not been taken into account in the calculation of the mean value, $63.2 \pm$ $2.3 \mathrm{~kJ} \mathrm{~mol}^{-1}$ (obtained using 13 data points 


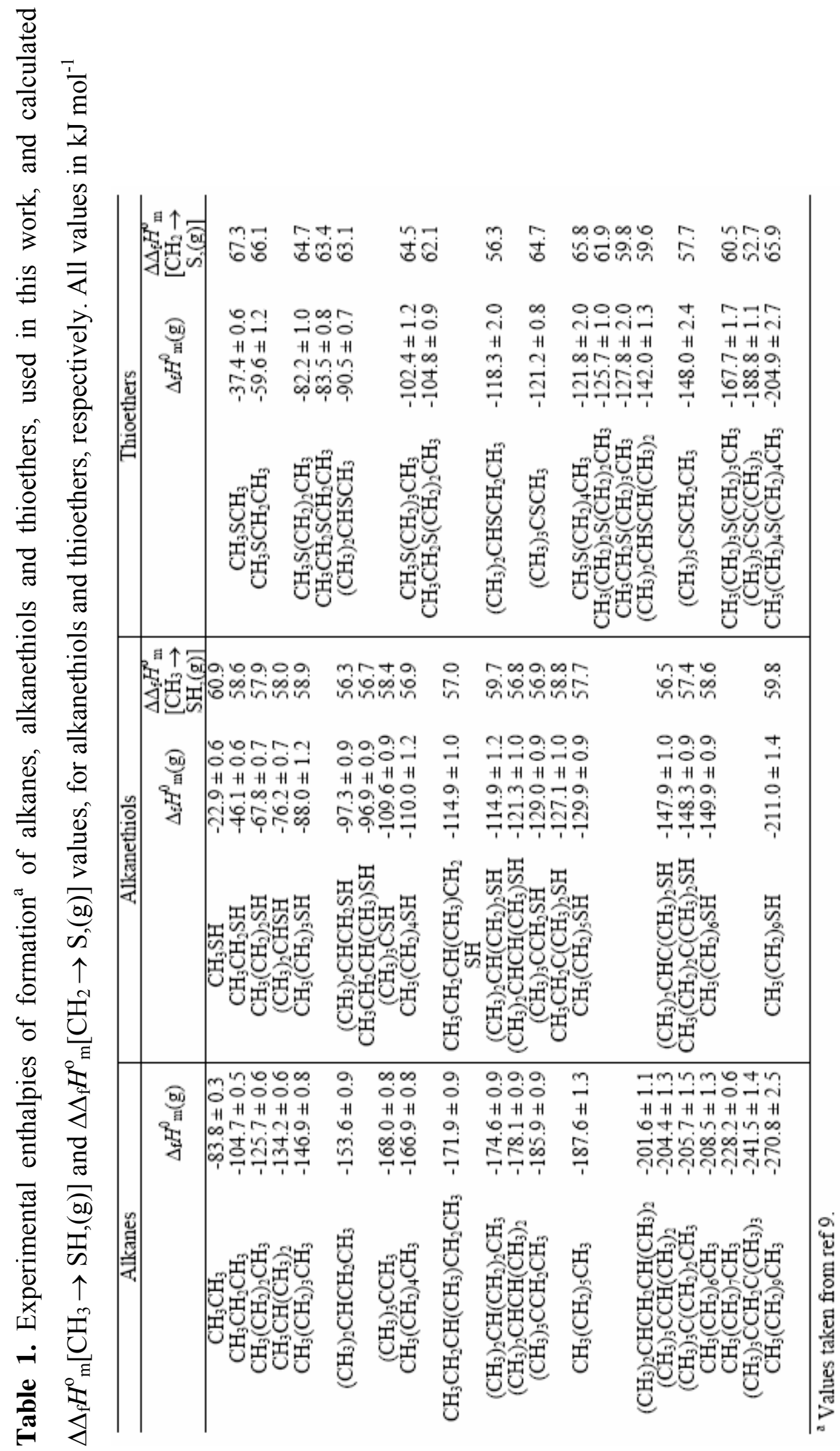


Table 2. Calculated $\Delta_{\mathrm{f}} H_{\mathrm{m}}^{0}(\mathrm{~g})$ values for alkanethiols and thioethers, using the $\Delta \Delta_{\mathrm{f}} H_{\mathrm{m}}^{0}\left[\mathrm{CH}_{3} \rightarrow\right.$ $\mathrm{SH},(\mathrm{g})]$ and $\Delta \Delta_{\mathrm{f}} \mathrm{H}_{\mathrm{m}}^{\mathrm{o}}\left[\mathrm{CH}_{2} \rightarrow \mathrm{S},(\mathrm{g})\right]$ values obtained in this work. All values in $\mathrm{kJ} \mathrm{mol}^{-1 \text { a }}$

\begin{tabular}{|c|c|c|c|c|c|}
\hline \multicolumn{3}{|c|}{ Alkanethiols } & \multicolumn{3}{|c|}{ Thioethers } \\
\hline & Calculated & $\delta^{\mathrm{a}}$ & & Calculated & $\delta^{\mathrm{a}}$ \\
\hline $\mathrm{CH}_{3} \mathrm{CH}_{2} \mathrm{SH}$ & $-46.9 \pm 1.2$ & 0.8 & $\mathrm{CH}_{3} \mathrm{SCH}_{2} \mathrm{CH}_{3}$ & $-62.5 \pm 2.4$ & 2.7 \\
\hline $\mathrm{CH}_{3}\left(\mathrm{CH}_{2}\right)_{2} \mathrm{SH}$ & $-67.9 \pm 1.3$ & 0.1 & $\mathrm{CH}_{3} \mathrm{~S}\left(\mathrm{CH}_{2}\right)_{2} \mathrm{CH}_{3}$ & $-83.7 \pm 2.4$ & 1.5 \\
\hline$\left(\mathrm{CH}_{3}\right)_{2} \mathrm{CHSH}$ & $-76.4 \pm 1.3$ & 0.2 & $\mathrm{CH}_{3} \mathrm{CH}_{2} \mathrm{SCH}_{2} \mathrm{CH}_{3}$ & $-83.7 \pm 2.4$ & 0.2 \\
\hline $\mathrm{CH}_{3}\left(\mathrm{CH}_{2}\right)_{3} \mathrm{SH}$ & $-88.2 \pm 1.4$ & 0.2 & $\left(\mathrm{CH}_{3}\right)_{2} \mathrm{CHSCH}_{3}$ & $-90.4 \pm 2.5$ & -0.1 \\
\hline$\left(\mathrm{CH}_{3}\right)_{2} \mathrm{CHCH}_{2} \mathrm{SH}$ & $-95.8 \pm 1.4$ & -1.5 & $\mathrm{CH}_{3} \mathrm{~S}\left(\mathrm{CH}_{2}\right)_{3} \mathrm{CH}_{3}$ & $-103.7 \pm 2.4$ & 1.3 \\
\hline $\mathrm{CH}_{3} \mathrm{CH}_{2} \mathrm{CH}\left(\mathrm{CH}_{3}\right) \mathrm{SH}$ & $-95.8 \pm 1.4$ & -1.1 & $\mathrm{CH}_{3} \mathrm{CH}_{2} \mathrm{~S}\left(\mathrm{CH}_{2}\right)_{2} \mathrm{CH}_{3}$ & $-103.7 \pm 2.4$ & -1.1 \\
\hline$\left(\mathrm{CH}_{3}\right)_{3} \mathrm{CSH}$ & $-110.2 \pm 1.4$ & 0.6 & $\left(\mathrm{CH}_{3}\right)_{3} \mathrm{CSCH}_{3}$ & $-122.7 \pm 2.5$ & 1.6 \\
\hline $\mathrm{CH}_{3}\left(\mathrm{CH}_{2}\right)_{4} \mathrm{SH}$ & $-109.1 \pm 1.4$ & -0.9 & $\mathrm{CH}_{3} \mathrm{~S}\left(\mathrm{CH}_{2}\right)_{4} \mathrm{CH}_{3}$ & $-124.4 \pm 2.6$ & 2.6 \\
\hline $\mathrm{CH}_{3} \mathrm{CH}_{2} \mathrm{CH}\left(\mathrm{CH}_{3}\right) \mathrm{CH}_{2} \mathrm{SH}$ & $-114.1 \pm 1.4$ & -0.8 & $\mathrm{CH}_{3}\left(\mathrm{CH}_{2}\right)_{2} \mathrm{~S}\left(\mathrm{CH}_{2}\right)_{2} \mathrm{CH}_{3}$ & $-124.4 \pm 2.6$ & -1.3 \\
\hline$\left(\mathrm{CH}_{3}\right)_{2} \mathrm{CH}\left(\mathrm{CH}_{2}\right)_{2} \mathrm{SH}$ & $-116.8 \pm 1.4$ & -1.5 & $\left(\mathrm{CH}_{3}\right)_{2} \mathrm{CHSCH}\left(\mathrm{CH}_{3}\right)_{2}$ & $-138.4 \pm 2.5$ & -3.6 \\
\hline$\left(\mathrm{CH}_{3}\right)_{2} \mathrm{CHCH}\left(\mathrm{CH}_{3}\right) \mathrm{SH}$ & $-120.3 \pm 1.4$ & -1.0 & $\mathrm{CH}_{3} \mathrm{CH}_{2} \mathrm{~S}\left(\mathrm{CH}_{2}\right)_{3} \mathrm{CH}_{3}$ & $-124.4 \pm 2.6$ & -3.4 \\
\hline$\left(\mathrm{CH}_{3}\right)_{3} \mathrm{CCH}_{2} \mathrm{SH}$ & $-128.1 \pm 1.4$ & -0.9 & $\mathrm{CH}_{3}\left(\mathrm{CH}_{2}\right)_{3} \mathrm{~S}\left(\mathrm{CH}_{2}\right)_{3} \mathrm{CH}_{3}$ & $-165.0 \pm 2.4$ & -2.7 \\
\hline $\mathrm{CH}_{3} \mathrm{CH}_{2} \mathrm{C}\left(\mathrm{CH}_{3}\right)_{2} \mathrm{SH}$ & $-128.1 \pm 1.4$ & 1.0 & $\mathrm{CH}_{3}\left(\mathrm{CH}_{2}\right)_{4} \mathrm{~S}\left(\mathrm{CH}_{2}\right)_{4} \mathrm{CH}_{3}$ & $-207.6 \pm 3.4$ & 2.7 \\
\hline $\mathrm{CH}_{3}\left(\mathrm{CH}_{2}\right)_{5} \mathrm{SH}$ & $-129.8 \pm 1.7$ & -0.1 & & & \\
\hline$\left(\mathrm{CH}_{3}\right)_{2} \mathrm{CHC}\left(\mathrm{CH}_{3}\right)_{2} \mathrm{SH}$ & $-146.6 \pm 1.7$ & -1.3 & & & \\
\hline $\mathrm{CH}_{3}\left(\mathrm{CH}_{2}\right)_{2} \mathrm{C}\left(\mathrm{CH}_{3}\right)_{2} \mathrm{SH}$ & $-147.9 \pm 1.9$ & -0.4 & & & \\
\hline $\mathrm{CH}_{3}\left(\mathrm{CH}_{2}\right)_{6} \mathrm{SH}$ & $-150.7 \pm 1.7$ & 0.8 & & & \\
\hline $\mathrm{CH}_{3}\left(\mathrm{CH}_{2}\right)_{9} \mathrm{SH}$ & $-213.0 \pm 2.7$ & -2.0 & & & \\
\hline
\end{tabular}

${ }^{\mathrm{a}} \delta=\Delta_{\mathrm{f}} H^{\mathrm{o}}{ }_{\mathrm{m}}(\exp )-\Delta_{\mathrm{f}} H^{\mathrm{o}}{ }_{\mathrm{m}}($ calc $)$.

With the $\Delta \Delta_{\mathrm{f}} H_{\mathrm{m}}^{\mathrm{o}}\left[\mathrm{CH}_{3} \rightarrow \mathrm{SH},(\mathrm{g})\right]$ and $\Delta \Delta_{\mathrm{f}} H_{\mathrm{m}}^{\mathrm{o}}\left[\mathrm{CH}_{2} \rightarrow \mathrm{S},(\mathrm{g})\right]$ values calculated above, it is now possible to estimate the enthalpies of formation of different alkanethiols or thioethers. We have first applied this method to the calculation of $\Delta_{\mathrm{f}} H_{\mathrm{m}}^{0}(\mathrm{~g})$ for the alkanethiols and thioethers used in the derivation of the $\Delta \Delta_{\mathrm{f}} H_{\mathrm{m}}^{\mathrm{o}}$ values. The results are collected in Table 2. The average deviation is $0.8 \mathrm{~kJ} \mathrm{~mol}^{-1}$ for alkanethiols, and $1.9 \mathrm{~kJ} \mathrm{~mol}^{-1}$ for thioethers.

A further step in the process of proving the validity of our predictions is to calculate $\Delta_{\mathrm{f}} H_{\mathrm{m}}^{0}(\mathrm{~g})$ values for a series of compounds containing the sulfide and/or thiol groups, and not used in the derivation of the $\Delta \Delta_{\mathrm{f}} H_{\mathrm{m}}^{0}$ values. Nine compounds have been found in the literature: cyclopentanethiol, cyclohexanethiol, cyclopentyl methyl sulfide, 3,5-dithiaheptane, 3,6dithiaoctane, and four alkanedithiols: 1,4-dithiabutane, 1,5-dithiapentane, 1,6-dithiahexane, and 1,7-dithiaheptane. The calculated $\Delta_{\mathrm{f}} H_{\mathrm{m}}^{0}(\mathrm{~g})$ values for all of these compounds are collected in Table 3. As it can be seen, a very good agreement is obtained between the experimental and calculated $\Delta_{\mathrm{f}} H_{\mathrm{m}}^{0}(\mathrm{~g})$ values.

Finally, we have calculated the enthalpies of formation of two compounds with unknown $\Delta_{\mathrm{f}} \mathrm{H}_{\mathrm{m}}^{0}(\mathrm{~g})$ value: a dithiol, 1,3-dithiapropane [or methanedithiol], $\mathrm{HSCH}_{2} \mathrm{SH}$, and a compound 
with - - - and - $\mathrm{SH}$ groups in the same molecule, 1,3,5-trithiapentane [or bis(mercaptomethyl)sulfide], $\mathrm{HSCH}_{2} \mathrm{SCH}_{2} \mathrm{SH}$. The values obtained are shown in Table 3.

Table 3. Calculated $\Delta_{\mathrm{f}} H_{\mathrm{m}}^{0}(\mathrm{~g})$ values for a series of sulfur compounds, using the $\Delta \Delta_{\mathrm{f}} H_{\mathrm{m}}^{\mathrm{o}}\left[\mathrm{CH}_{3} \rightarrow\right.$ $\mathrm{SH},(\mathrm{g})]$ and $\Delta \Delta_{\mathrm{f}} \mathrm{H}_{\mathrm{m}}^{\mathrm{o}}\left[\mathrm{CH}_{2} \rightarrow \mathrm{S},(\mathrm{g})\right]$ values calculated in this work. All values in $\mathrm{kJ} \mathrm{mol}^{-1}$

\begin{tabular}{|c|c|c|}
\hline \multirow[b]{2}{*}{ Compound } & \multicolumn{2}{|c|}{$\Delta_{\mathrm{f}} H^{\mathrm{o}}{ }_{\mathrm{m}}(\mathrm{g})$} \\
\hline & Calculated & Experimental $^{\mathrm{a}}$ \\
\hline $\mathrm{c}-\mathrm{C}_{5} \mathrm{H}_{9} \mathrm{SH}$ & $-48.4 \pm 1.3$ & $-48.1 \pm 0.9$ \\
\hline $\mathrm{c}-\mathrm{C}_{6} \mathrm{H}_{11} \mathrm{SH}$ & $-96.8 \pm 1.5$ & $-96.2 \pm 0.9$ \\
\hline $\mathrm{c}-\mathrm{C}_{5} \mathrm{H}_{9} \mathrm{SCH}_{3}$ & $-63.7 \pm 2.5$ & $-64.7 \pm 1.0$ \\
\hline $\mathrm{CH}_{3} \mathrm{CH}_{2} \mathrm{SCH}_{2} \mathrm{SCH}_{2} \mathrm{CH}_{3}$ & $-61.2 \pm 3.5$ & $-65.2 \pm 1.5^{b}$ \\
\hline $\mathrm{CH}_{3} \mathrm{CH}_{2} \mathrm{~S}\left(\mathrm{CH}_{2}\right)_{2} \mathrm{SCH} 2 \mathrm{CH} 3$ & $-82.1 \pm 3.5$ & $-83.0 \pm 1.5^{b}$ \\
\hline $\mathrm{HS}\left(\mathrm{CH}_{2}\right)_{2} \mathrm{SH}$ & $-10.1 \pm 1.7$ & $-9.7 \pm 1.2$ \\
\hline $\mathrm{HS}\left(\mathrm{CH}_{2}\right)_{3} \mathrm{SH}$ & $-31.3 \pm 1.7$ & $-29.8 \pm 1.2$ \\
\hline $\mathrm{HS}\left(\mathrm{CH}_{2}\right)_{4} \mathrm{SH}$ & $-51.3 \pm 1.7$ & $-50.6 \pm 1.8$ \\
\hline $\mathrm{HS}\left(\mathrm{CH}_{2}\right)_{5} \mathrm{SH}$ & $-72.0 \pm 2.0$ & $-71.0 \pm 1.4$ \\
\hline $\mathrm{HSCH}_{2} \mathrm{SH}$ & $10.9 \pm 1.6$ & ----- \\
\hline $\mathrm{HSCH}_{2} \mathrm{SCH}_{2} \mathrm{SH}$ & $31.9 \pm 2.9$ & ----- \\
\hline
\end{tabular}

${ }^{\mathrm{a}}$ Values taken from ref 9, unless otherwise noted ${ }^{\mathrm{b}}$ Value taken from ref 20.

With the purpose of checking the accuracy of the estimated enthalpies of formation of the above mentioned two compounds, we have also carried out a theoretical study, calculating their enthalpies of formation at the G2(MP2), G2 and G3 levels. These methods have been previously used by $\mathrm{us}^{21-29}$ for the calculation of the enthalpies of formation of different compounds containing S atoms: thiirane, ${ }^{21}$ thiane, ${ }^{21,22} 1,3$ - and 1,4-dithiane, ${ }^{21} 1,3,5$-trithiane, ${ }^{22} 2$ - and 3thiophenecarboxylic acids, ${ }^{23}$ thiane sulfoxide and thiane sulfone, ${ }^{24} 1,3$-dithiane sulfone, ${ }^{26}$ and 1,3-dithiane sulfoxide. ${ }^{27}$ In all the cases, a good agreement between experimental and theoretical results was obtained.

The most stable conformers of both studied compounds are in gauche, gauche conformation (anomeric effect) as it is well $\mathrm{known}^{30,31}$ in the case of $\mathrm{HSCH}_{2} \mathrm{SH}$. To our knowledge, there is not any conformational study in the literature for $\mathrm{HSCH}_{2} \mathrm{SCH}_{2} \mathrm{SH}$. The MP2(FULL)/6-31G(d)-optimized structures are drawn in Figure 1.

Calculated energies at $0 \mathrm{~K}$, and enthalpies at $298 \mathrm{~K}$, for 1,3-dithiapropane and 1,3,5trithiapentane are given in Table 4. 


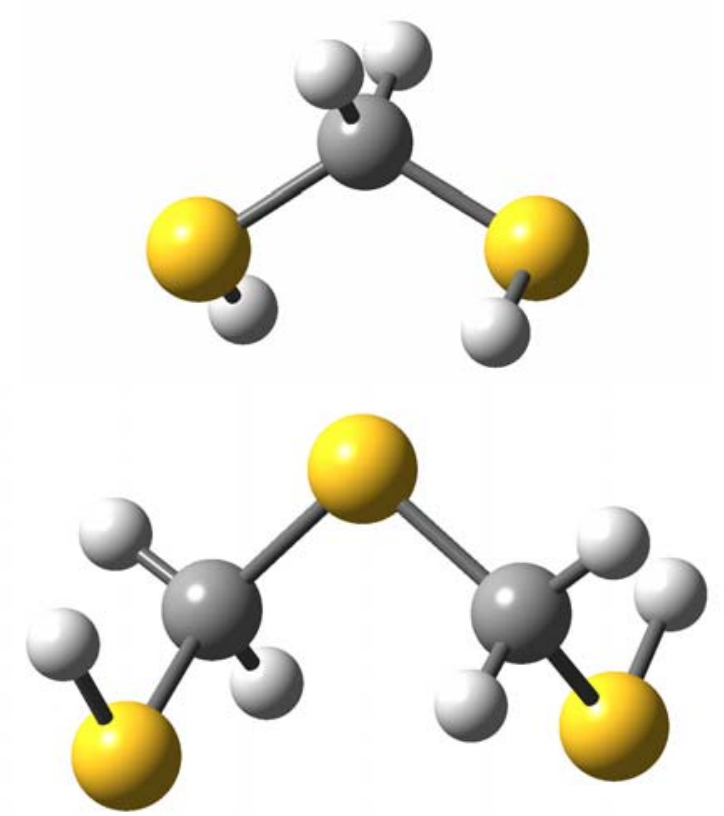

Figure 1. MP2(FULL)/6-31G(d)-optimized structures of 1,3-dithiapropane and 1,3,5trithiapentane.

Table 4. G2(MP2), G2 and G3 total energies at $0 \mathrm{~K}$, and enthalpies at $298 \mathrm{~K}$, for 1,3dithiapropane and 1,3,5-trithiapentane. All values in Hartrees

\begin{tabular}{ccccccc}
\hline & \multicolumn{2}{c}{ G2(MP2) } & \multicolumn{2}{c}{ G2 } & \multicolumn{2}{c}{ G3 } \\
\cline { 2 - 7 } Compound & $E_{0}$ & $H_{298}$ & $E_{0}$ & $H_{298}$ & $E_{0}$ & $H_{298}$ \\
\hline 1,3-dithiapropane & - & - & - & - & - & - \\
& 835.87847 & 835.87276 & 835.89167 & 835.88595 & 836.55170 & 836.54598 \\
$1,3,5-$ & - & - & - & - & - & - \\
trithiapentane & 1272.8435 & 1272.8349 & 1272.8632 & 1272.8547 & 1273.8756 & 1273.8671 \\
& 0 & 8 & 8 & 6 & 6 & 4 \\
\hline
\end{tabular}

In standard Gaussian-n theories, theoretical enthalpies of formation are calculated through atomization reactions (5) and (6). We have detailed this method in previous studies. ${ }^{32,33}$

$$
\begin{aligned}
& \mathrm{CH}_{4} \mathrm{~S}_{2}(\mathrm{~g}) \rightarrow \mathrm{C}(\mathrm{g})+4 \mathrm{H}(\mathrm{g})+2 \mathrm{~S}(\mathrm{~g}) \\
& \mathrm{C}_{2} \mathrm{H}_{6} \mathrm{~S}_{3}(\mathrm{~g}) \rightarrow 2 \mathrm{C}(\mathrm{g})+6 \mathrm{H}(\mathrm{g})+3 \mathrm{~S}(\mathrm{~g})
\end{aligned}
$$

Raghavachari et al. ${ }^{34}$ have proposed to use a standard set of isodesmic reactions, the "bond separation reactions", ${ }^{35}$ to derive the theoretical enthalpies of formation. This method has been detailed in previous studies. ${ }^{32,33}$ 
The bond separation reactions for 1,3-dithiapropane and 1,3,5-trithiapentane are, respectively:

$$
\begin{aligned}
& \mathrm{CH}_{4} \mathrm{~S}_{2}(\mathrm{~g})+\mathrm{CH}_{4}(\mathrm{~g}) \rightarrow 2 \mathrm{CH}_{3} \mathrm{SH}(\mathrm{g}) \\
& \mathrm{C}_{2} \mathrm{H}_{6} \mathrm{~S}_{3}(\mathrm{~g})+2 \mathrm{CH}_{4}(\mathrm{~g})+\mathrm{H}_{2} \mathrm{~S}(\mathrm{~g}) \rightarrow 4 \mathrm{CH}_{3} \mathrm{SH}(\mathrm{g})
\end{aligned}
$$

The $\Delta_{\mathrm{f}} \mathrm{H}_{\mathrm{m}}^{\mathrm{o}}$ calculated values, at the G2(MP2), G2 and G3 levels, using both atomization and isodesmic bond separation reactions, are shown in Table 5. The averages of the values calculated at the different Gn levels from atomization and bond separation isodesmic reactions, 16.3 and $27.7 \mathrm{~kJ} \mathrm{~mol}^{-1}$, for 1,3-dithiapropane and 1,3,5-trithiapentane, respectively, are in reasonable agreement with the values previously estimated in this work, 10.9 and $31.9 \mathrm{~kJ} \mathrm{~mol}^{-1}$, respectively, within the uncertainties associated to Gaussian-n methods.

Table 5. Calculated enthalpies of formation for the studied compound at the G2(MP2), G2 and

\begin{tabular}{|c|c|c|c|c|c|c|}
\hline \multirow[b]{2}{*}{ Compound } & \multicolumn{2}{|c|}{ G2(MP2) } & \multicolumn{2}{|c|}{$\mathrm{G} 2$} & \multicolumn{2}{|c|}{ G3 } \\
\hline & atomization & $\begin{array}{c}\text { Bond } \\
\text { separation }\end{array}$ & atomization & $\begin{array}{c}\text { bond } \\
\text { separation }\end{array}$ & atomization & $\begin{array}{c}\text { bond } \\
\text { separation }\end{array}$ \\
\hline $\begin{array}{c}1,3- \\
\text { dithiapropane }\end{array}$ & $11.0(17.0)^{\mathrm{a}}$ & 15.4 & $19.2(17.3)^{\mathrm{a}}$ & 15.4 & 18.5 & 14.3 \\
\hline $\begin{array}{c}1,3,5- \\
\text { trithiapentane }\end{array}$ & $19.9(30.3)^{\mathrm{a}}$ & 25.6 & $33.0(30.9)^{\mathrm{a}}$ & 25.7 & 30.1 & 23.4 \\
\hline
\end{tabular}
$\mathrm{G} 3$ levels using both atomization and bond separation isodesmic reactions. All values in $\mathrm{kJ} \mathrm{mol}^{-1}$

${ }^{a}$ Value obtained from atomization reaction including spin-orbit and bond additivity corrections.

This method has been detailed in ref 24

\section{Computational Details}

Standard ab initio molecular orbital calculations ${ }^{35}$ were performed with the Gaussian03 series of programs. ${ }^{36}$ The energies of the studied compounds were calculated using Gaussian-n theories, at the $\mathrm{G} 2(\mathrm{MP} 2),{ }^{37} \mathrm{G} 2^{38}$ and $\mathrm{G} 3^{39}$ levels.

G2(MP2) and G2 correspond effectively to calculations at the QCISD(T)/6-311+G(3df,2p) level on MP2(full)/6-31G(d)-optimized geometries, incorporating scaled HF/6-31G(d) zero-point vibrational energies and a so-called higher-level correction to accommodate remaining deficiencies.

The scheme of G3 theory is similar to that of G2, but the MP2 single-point energy calculation is performed with a new basis set, referred to as G3large that includes core correlation. So, G3 is effectively at the QCISD(T,full)/G3large level, making certain 
assumptions about the additivity of the calculations. It also includes a spin-orbit correction for atomic species only. The higher-level empirical correction is now different for atoms and for molecules.

\section{Acknowledgements}

The support of the Spanish MEC/DGI under the Projects BQU2003-05827 and FIS2004-02954C03-01 is gratefully acknowledged.

\section{References}

1. Liebman, J. F.; Greenberg, A. Eds., Molecular Structure and Energetics, VCH Publishers: New York, 1986; Vol 1.

2. Cox, J. D.; Pilcher, G. Thermochemistry of Organic and Organometallic Compounds, Academic Press: London, 1970.

3. Minas da Piedade, M. E., Ed.; Energetics of Stable Molecules and Reactive Intermediates, Kluwer Academic Publishers: Dordrecht, The Netherlands, 1999; NATO Science Series C, Vol 535.

4. Laidler, K. J. Can. J. Chem. 1956, 34, 626.

5. Allen, T. L. J. Chem. Phys. 1959, 31, 1039.

6. Pihlaja, K.; Rossi, K.; Vainiotalo, P. J. Chem. Eng. Data 1985, 30, 387.

7. Benson, S. W.; Buss, J. H. J. Chem. Phys. 1958, 29, 546.

8. Cohen, N.; Benson, S. W. Chem. Rev. 1993, 93, 2419.

9. Pedley, J. B. Thermochemical Data and Structures of Organic Compounds, TRC: College Station, TX, 1994; Vol. 1.

10. Smith, D. W. J. Chem. Soc., Faraday Trans. 1996, 92, 1141.

11. Smith, D. W. J. Chem. Soc., Faraday Trans. 1997, 93, 2037.

12. Slayden, S. W.; Liebman, J. F. Thermochemistry of Ethers, Alcohols, Arenols, Enols and Peroxides, Patai, S., Ed.; Chem. Hydroxyl, Ether Peroxide Groups; Wiley: Chichester, UK, 1993; Ch. 4.

13. Prosen, E. J.; Johnson, W. H.; Rossini, F. D. J. Res. Natl. Bur. Stand. 1946, 37, 51.

14. Sellers, P.; Stridh, G.; Sunner, S. J. Chem. Eng. Data 1978, 23, 250.

15. Wiberg, K. B.; Wasserman, D. J.; Martin, E. J. Phys. Chem. 1984, 88, 3684.

16. Wiberg, K. B. Experimental Thermochemistry, In Molecular Structure and Energetics, Physical Measurements, Liebman, J. F.; Greenberg, A., Eds.; VCH Publishers: New York, 1987; Vol 2, Ch. 4. 
17. Pihlaja, K. Thermochemical Methods in the Structural Analysis of Organic Compounds, In Molecular Structure and Energetics, Physical Measurements, Liebman, J. F.; Greenberg, A., Eds; VCH Publishers: New York, 1987; Ch. 5, Vol 2.

18. Good, W. D.; DePrater, B. L. J. Phys. Chem. 1966, 70, 3606.

19. Stull, D. R.; Westrum, E. F.; Sinke, G. C. The Chemical Thermodynamics of Organic Compounds, Wiley: New York, 1969.

20. Afeefy, H. Y.; Liebman, J. F.; Stein, S. E. "Neutral Thermochemical Data" In NIST Chemistry WebBook, NIST Standard Reference Database Number 69, Linstrom, P. J.; Mallard, W. G., Eds.; June 2005, National Institute of Standards and Technology, Gaithersburg MD, 20899 (http://webbook.nist.gov).

21. Dávalos, J. Z.; Flores, H., Jiménez, P.; Notario, R.; Roux, M.V.; Juaristi, E.; Hosmane, R. S.; Liebman, J. F. J. Org. Chem. 1999, 64, 9328.

22. Roux, M.V.; Jiménez, P.; Dávalos, J. Z.; Notario, R.; Juaristi, E. J. Org. Chem. 2001, 66, 5343.

23. Temprado, M.; Roux, M.V.; Jiménez, P.; Dávalos, J. Z.; Notario, R. J. Phys. Chem. A 2002, 106, 11173.

24. Roux, M. V.; Temprado, M.; Jiménez, P.; Dávalos, J. Z.; Notario, R.; Guzmán-Mejía, R.; Juaristi, E. J. Org. Chem. 2003, 68, 1762.

25. Roux, M.V.; Jiménez, P.; Notario, R.; Juaristi, E. In Trends in Physical Chemistry, 2003; Vol 9, pp129-139.

26. Roux, M.V.; Temprado, M.; Jiménez, P.; Notario, R.; Guzmán-Mejía, R.; Juaristi, E. J. Org. Chem. 2004, 69, 1670.

27. Roux, M. V.; Temprado, M.; Jiménez, P.; Dávalos, J. Z.; Notario, R.; Martín-Valcárcel, G.; Garrido, L.; Guzmán-Mejía, R.; Juaristi, E. J. Org. Chem. 2004, 69, 5454.

28. Juaristi, E.; Notario, R.; Roux, M. V. Chem. Soc. Rev. 2005, 34, 347.

29. Roux, M. V.; Jiménez, P.; Notario, R.; Temprado, M.; Martín-Valcárcel, G.; Liebman, J. F. ARKIVOC 2005, (ix), 364.

30. Salzner, U.; Schleyer, P. V. R. J. Am. Chem. Soc. 1993, 115, 10231.

31. Chang, Y.-P.; Su, T.-M. J. Phys. Chem A 1999, 103, 8706.

32. Notario, R.; Castaño, O.; Abboud, J.-L. M.; Gomperts, R.; Frutos, L.M.; Palmeiro, R. J. Org. Chem. 1999, 64, 9011.

33. Notario, R.; Castaño, O.; Gomperts, R.; Frutos, L. M.; Palmeiro, R. J. Org. Chem. 2000, 65, 4298.

34. Raghavachari, K.; Stefanov, B. B.; Curtiss, L. A. J. Chem. Phys. 1997, 106, 6764.

35. Hehre, W. J.; Radom. L.; Schleyer, P. V. R.; Pople, J. A. Ab Initio Molecular Orbital Theory, Wiley: New York, 1986.

36. Gaussian 03, Revision B.05, Frisch, M. J.; Trucks, G. W.; Schlegel, H. B.; Scuseria, G. E.; Robb, M. A.; Cheeseman, J. R.; Montgomery, J. A. Jr.; Vreven, T.; Kudin, K. N.; Burant, J. C.; Millam, J. M.; Iyengar, S. S.; Tomasi, J.; Barone, V.; Mennucci, B.; Cossi, M.; Scalmani, G.; Rega, N.; Petersson, G. A.; Nakatsuji, H.; Hada, M.; Ehara, M.; Toyota, K.; 
Fukuda, R.; Hasegawa, J.; Ishida, M.; Nakajima, T.; Honda, Y.; Kitao, O.; Nakai, H.; Klene, M.; Li, X.; Knox, J. E.; Hratchian, H. P.; Cross, J. B.; Adamo, C.; Jaramillo, J.; Gomperts, R.; Stratmann, R. E.; Yazyev, O.; Austin, A. J.; Cammi, R.; Pomelli, C.; Ochterski, J. W.; Ayala, P. Y.; Morokuma, K.; Voth, G. A.; Salvador, P.; Dannenberg, J. J.; Zakrzewski, V. G.; Dapprich, S.; Daniels, A. D.; Strain, M. C.; Farkas, O.; Malick, D. K.; Rabuck, A. D.; Raghavachari, K.; Foresman, J. B.; Ortiz, J. V.; Cui, Q.; Baboul, A. G.; Clifford, S.; Cioslowski, J.; Stefanov, B. B.; Liu, G.; Liashenko, A.; Piskorz, P.; Komaromi, I.; Martin, R. L.; Fox, D. J.; Keith, T.; Al-Laham, M. A.; Peng, C. Y.; Nanayakkara, A.; Challacombe, M.; Gill, P. M. W.; Johnson, B.; Chen, W.; Wong, M. W.; Gonzalez, C. and Pople, J. A. Gaussian, Inc., Pittsburgh PA, 2003.

37. Curtiss, L. A.; Raghavachari, K.; Trucks, G. W.; Pople, J. A. J. Chem. Phys. 1991, 94, 7221.

38. Curtiss, L. A.; Raghavachari, K.; Pople, J. A. J. Chem. Phys. 1993, 98, 1293.

39. Curtiss, L. A.; Raghavachari, K.; Redfern, P. C.; Rassolov, V.; Pople, J. A. J. Chem. Phys. 1998, 109, 7764 . 